\title{
Ownership Characteristics of Strata Property Rights
}

\author{
DR. J.Andy Hartanto., SH., MH.,Sp.N., Ir., MMT \\ Law Faculty, Narotama University, Surabaya, Indonesia
}

\begin{abstract}
Related to the housing construction, some regulations have been adopted several times by the Indonesian government. Under the Act of Housing and Settlement Region, the forms of houses are divided into three categories: single houses, row houses, and apartments. The difference between a single house and a row house lies only in the sides of the building. The sides of the buildings of row houses are fused with the one or more other buildings. While a single house has its own plot and one of the walls of the building is not built right on the line of the boundary plots. Not all multi-storey buildings are subject to the provisions of flats. Single Ownership is implemented in the regulation of the storey-buildings so that it is not subject to the provisions of flats. While the storey buildings divided into sections/parts can be owned separately although they are not separeted with the common parts. They are Multy Ownership and subject to the provisions of strata. Ownership characteristics on strata are not the same as on residential and other buildings.
\end{abstract}

Keywords: storey-houses, buildings, land.

\section{Introduction}

In relation to housing construction, Indonesian government has issued some regulations in the areas of housing several times, among others, Act No. 1 of 1964 concerning the Stipulation of Government Regulation in Lieu of Act No. 6 of 1962 on the Principles of Housing into the Act, Act No. 4 of 1992 on Housing and Settlement, and the last one is Act No. 1 of 2011 on Housing and Settlement Region.

Under the Act of Housing and Settlement Region, the forms of the house are divided into three kinds: single houses, row houses, and flats. The difference between a single home and a row home lies only in the sides of the building. In the row house, the sides of the building are blended with the one or more of other buildings. On the other hand, a single house has its own plots and one of the building walls is not built right on the boundary of the plots. Under the Article 46 of Act on Housing and the Settlement Region, strata are separately regulated in an act. Under the provisions of Article 46, Act No. 20 of 2011 on strata (UURS) was then issued. Since the implementation of the UURS regulations has not existed yet, the Government Regulation No. 4 of 1988 regulating the implementation of the old Flat Act No. 16 of 1985 is still run as long as it is not contrary to UURS.

In Indonesia, the law of land is based on the customary law (Adat Law). The Adat Law does not recognize the principles of the attachments set in BW, but it implements the principles of horizontal separation (Horizontale Van Scheiding) stating that the ownership of a piece of land and everything on it is separated. The principles of horizontal separation regulate the land with its attaching objects. Ter Haar states, as quoted by Imam Sudiyat, that the land is separated from everything attached to it or the ownership of the land is regardless of the objects on it. It means that the owner of the land and building can be different (Imam Sudiyat, 1981: 54). According to J. Kartini Sudjendro, there are some lands which are regulated by Adat Agraian Law and some are by Western Agrarian Law. The pieces of land subject to Adat Agraian Law are land of ulayat (common lands), lands belonging to a foundation, land for bussiness and gogolan, and the ones subject to Western Agrarian Law include eigendom land, erfpacht land, and opstal land. (J. Kartini Soedjendro, 2005: 49).

How are the ownership characteristics of strata in Indonesia, especially when it is compared to the ownership characteristics of the buildings as regulated in Act Number 28 of 2002 ?

\section{Library Studies}

The construction of multi-storey building as a residence or dwelling is stipulated in not only UURS, but also in the regulations of Act No. 28 of 2002. Article 1 of Act No. 28 of 2002 states that the building is a physical manifestation of the work of construction fused with its position partially or wholly on a piece of land or in it and or water, which serves as a place where people perform activities for both residential or dwelling, religious, business, social, cultural activities and special events. The ratio of joint occupation over a piece of land on which it stands, strata have a strong legal basis, namely Article 4 paragraph 1 jo. Article 2 of UUPA which indicates that the rights on land can be owned or occupied jointly with other parties. While the provisions of UURS are the basis for stipulating the strata. The rules of strata start in the provisions of UUPA, so that 
the process of the development, the ownership and the transfer of ownership is obliged to the rules stated in UUPA. Thus the rules of UURS must not be contrarary with the ones in UUPA.

The most important aspect of the law of the land is about the relationship between the land and the objects attached to it. The assurance of the legal position of objects attached to the land is very important because it concerns the far-reaching influence on all legal relations related to the objects attached to the land (Djuhaendah Hasan, 1996: 65). The legal position of the rights on the strata is very important in the legal framework of land. For the comparison, the section 4 (2) Conveyancing (Strata Title) Act 1961 (NSW) states the constraints of strata: "unless otherwise stipulated in the strata plan, the common boundary of any lot with another lot or with common property shall be the center of the floor, wall or ceiling, as the case may be "(Alex Ilkin, 2007: 28). The definition of strata in a "floor plan" in s 5 (1) and of s 5 (2) (Alex Ilkin, 2007: 26): as regards the vertical boundaries; as regards the horizontal boundaries.

There are three (3) conclusions related to the boundaries. First, the boundaries between two interconnected strata or between two strata and common property are walls, floors, roofs, which divide the two strata or a unit and the common property and it is called The Centre Line Rule. Second, the center line rule does not apply to the division of the walls, floors and roofs in the case of a surveyor who drew the plan of the strata plan specifying the different boundaries in the plan. Third, the center line rule applies to walls, floors and roof of the strata which divide one by the other unit, or strata with common property.

The definition of the boundaries under Section 4 (2) of the Conveyancing (Strata Titles) Act 1961 (NSW) states the wall is fused into a multy ownership property so that the corporation would be responsible for the maintenance, repair and renewal or replacement, including the damage.

Meanwhile, Article 46 paragraph (1) and (2) UURS determines that the ownership of the property right on the strata is individual and seperated. The ownership of strata includes the right of co-ownership over the socalled common parts, common land, where everything is an integral part with the possession of the strata concerned.

The separated, individual parts are managed by the owner of the strata concerned, while the joint, shared objects and land are managed jointly by all owners of the strata through the Tenant Association and owners of the strata (PPPSRS). The requirements that must be fulfilled by the owners of the strata are subject to the provisions of the subject over the land rights as stipulated in the UUPA, and Government Regulation Number 40 of 1996.

According to Australian law, common/general properties contained in Section 5 (1) of the Development Act "internal features or structures within the external boundaries of a lot depicted by the surveyor on the plan should only be common property in nature" (Alex Ilkin , 2007: 30). The wall separating the strata from the common properties, strata with other strata or separate parts of the strata is a common property. The wall between the strata and connected to the balcony, between a villa or a house and garden area is common property, but if the wall is not drawn in the plan of the strata, it is the part of the strata, and not the common property. As for the square meter of space, it includes the part of strata as it is seen in the plan of the strata except the square meter of structural space and internal wall are the common property.

The boundary of the strata under transitional provision of the Development Act, "unless the surveyor who drew the plan stipulated a different strata boundary on the strata plan, if by s (2) of the 1961 Act the center line rule applied to the wall, floor and ceiling was then repositioned to be the inner surface of the wall, the upper surface of the floor and the under surface of the ceiling respectively "(Alex Ilkin, 2007: 28) (in translation" unless otherwise provided by the surveyor drawing plan flats, if according to s 4 (2) 1961 law "the center line" applies to walls, roofs and floors, and since July 1, 1974 in the form of barrier walls, roof and floor was repositioned as the surface of the wall, part upper surface of the floor, and the lower surface of the roof ").

In Indonesia the certificate of strata ownership has a specific characteristic and it is different from the certificate of the land ownership. All strata built on the land of any kinds of status such as land of ownership right, building use right, or the right to use on state land have the same certificate - it is certificate of strata ownership.

\section{Research Methods}

The legal materials required in this study are primary and secondary. The primary legal materials are materials in which its existence is based on or produced by a particular authority, such as acts and other regulations as long as the material are related to the problem under study. The secondary legal materials are materials that are found through the study of literature, for example by means of a scientific paper in the form of literature, scientific journals, as well as other scientific information. The study was conducted in two phases, namely the collection of legal materials and the assessment or analysis of it. The collection of the legal materials was done through the inventory of positive law and literature study associated with the problems under study. All the legal materials collected were then organized and classified in accordance with the legal formulation of the problem, the purpose of research and the system in writing the results. 


\section{Results and Discussion}

The following table gives some differences between the property rights of strata and land ownership:

\begin{tabular}{|l|l|}
\hline \multicolumn{1}{|c|}{ Freehold Strata } & \multicolumn{1}{|c|}{ Freehold Land } \\
\hline Rights associated with the land & Land rights \\
\hline $\begin{array}{l}\text { The subject must be able to be the subject of rights } \\
\text { over the land on which the strata is built }\end{array}$ & $\begin{array}{l}\text { Which may be the subject of law is Indonesian citizens } \\
\text { and certain legal entities stipulated in Government } \\
\text { Regulation No. 38 of } 1963\end{array}$ \\
\hline Duration depends on land rights & Unlimited period of time \\
\hline $\begin{array}{l}\text { It is privately and separately owned part completed } \\
\text { with its rights of common parts, objects, and land. }\end{array}$ & Have the nature of full ownership \\
\hline
\end{tabular}

Setting the period of the property right of strata can be described as follows (Urip Agus Santoso and Sekarmadji, 2003: 339-340):

a. If the strata is built on a piece of land with its ownership rights, the period of the occupancy is not limited by a specific period of time. It is because one of the characteristics of the ownership rights over the property is hereditary in which its right is not limited by a certain period so that it can switch and be transferred from one generation to the next generation on the condition that the owners qualify as the subject of land titles.

b. If the strata is built on a piece of land with its rights to use the building, the period of its occupancy under the Government Regulation Number 40 of 1996 is for a maximum of 30 (thirty) years the first time, can be extended for a maximum period of 20 (twenty) years for the second time, and renewed for a maximum period of 30 (thirty) years for the nest time.

c. If the strata is built on a piece of land with its use rights, the period of its occupancy under Regulation Number 40 of 1996 is for a maximum of 25 (twenty five) years for the first time, can be extended for a maximum period of 20 (twenty) years for the second time, and renewed for a maximum period of 25 (twenty five) years for the third time.

One of the rights possessed by the owner of the strata is related to the transtitional property rights of the trata from the owner to another party.

UURS does not specifically regulate the transtitional right of the strata title. Only Article 43 of UURS states that there is a process of purchasing and selling before the strata is constructed, and Article 44 governs the process of purchasing and selling of the strata conducted after it is completed. It is different from the provisions of Act No. 16 of 1985 which state that the ownership rights of the property to the strata can be switched from the owner to another party, and transferred from the owner to another party as it is set forth in Article 10. The explanation of Article 10 paragraph 1 of Law No. 16 of 1985 gives the sense that the switch means the transfer of rights by operation of law, while the transfer of rights is a legal act done by transferring the rights to another party, such as through the sale and purchase, exchange, and grants, investment in the company's capital, and auction.

Under the provisions of Article 37 paragraph (1) the Government Regulation No. 24 of 1997 it is stated that the switchover of the property right of strata except through an auction can be registered only if it is evidenced by a deed issued by the authorizing PPAT in accordance with the running laws and regulations. The recipient in the transition of the property right of strata is an important consideration whether it is inheritance, or transfer of rights and it must qualify as the property subject of the strata.

The following is the difference of the property rights of strata in Indonesia and Australia:

\begin{tabular}{|l|l|}
\hline \multicolumn{1}{|c|}{$\begin{array}{c}\text { Property rights of Strata } \\
\text { in Indonesia }\end{array}$} & \multicolumn{1}{c|}{$\begin{array}{c}\text { Property rights of Strata } \\
\text { in Australia }\end{array}$} \\
\hline $\begin{array}{l}\text { The right holder is a legal entity recorded in the } \\
\text { Certificate of Ownership Rights to Strata }\end{array}$ & $\begin{array}{l}\text { The right holder is a legal entity that is recorded in the } \\
\text { General Register }\end{array}$ \\
\hline $\begin{array}{l}\text { The Developer is responsible for managing the strata } \\
\text { for a maximum period of 1 year until PPPSRS is } \\
\text { established }\end{array}$ & All rights are the responsibility of the corporation. \\
\hline $\begin{array}{l}\text { There is no clear, strict stipulation about the } \\
\text { existence of the wall. It only differentiates the } \\
\text { common objects, parts and land. }\end{array}$ & $\begin{array}{l}\text { It is clearly stipulated about the existence of the wall. If } \\
\text { the wall abuts, it is the common property. If it does not } \\
\text { abut by the other party, it is not the common property. }\end{array}$ \\
\hline $\begin{array}{l}\text { The owner of the strata must be be the subject of } \\
\text { land rights where the strata is built }\end{array}$ & Each person can buy strata. \\
\hline
\end{tabular}




\section{Conclusion}

Not all multi-story buildings is subject to the provisions of strata. Story buildings with Single Ownership are not subject to the provisions of strata. While the story buildings which are divided into sections can be owned separately (Multy Ownership) but it is not independent with the common parts, objects and land that are subject to the provisions of strata. The property rights of strata have the characteristics which are different from the ones of the property rights on residential and other buildings. A person can have his individual property rights of strata separately but the common parts, objects and land are not. It means that the owner of the strata is still obliged to pay for all the damages in the common objects, and responsible for the cost of the extension or renewal of the collective land rights when the right has expired.

\section{Suggestion}

Highly considering the ownership characteristics of property rights to strata which are different from the ones of buildings in general, it is necessary to set more detailed in: the seller and buyer requirements, the mechanism of purchasing and selling, the rights and obligations of the seller and the buyer after the purchasing process, especially during the transition period.

\section{Bibliography}

[1]. Hasan, Djuhaendah, Lembaga Jaminan Kebendaan bagi Tanah dan Benda Lain yang Melekat pada Tanah dalam Konsepsi Penerapan Asas Pemisahan Horisontal, Citra Aditya Bakti, Bandung, 1996.

[2]. Harsono, Boedi, Hukum Agraria Indonesia, Sejarah Pembentukan Undang-undang Pokok Agraria, Isi dan Pelaksanaanya, Djambatan, Jakarta, 1997.

[3]. Ilkin, Alex, NSW Strata and Community Schemes Management and The Law, Thompson Lawbook Co, Sidney, 2007.

[4]. Kartini, J. Soedjendro, Perjanjian Peralihan Hak atas Tanah yang Berpotensi Konflik, Penerbit Kanisius, Yogyakarta, cetakan ke 5, 2005.

[5]. Peraturan Pemerintah Nomor 24 Tahun 1997 Tentang Pendaftaran Tanah (Lembaran Negara 1997 Nomor 59, Tambahan Lembaran Negara Nomor 3696).

[6]. Santoso, Urip, Disertasi Hak Pengelolaan dalam Sistem Hukum tanah Nasional, Universitas Airlangga, 2011.

[7]. Sudiyat, Imam, Hukum Adat Sketsa Asas, Liberty, Yogyakarta, 1981.

[8]. Santoso, Urip, Pengaturan Hak Milik atas Satuan Rumah Susun Dalam Hukum Nasional, Yuridika, Surabaya, 2003.

[9]. Undang-Undang Nomor 16 Tahun 1985 Tentang Rumah Susun (Lembaran Negara Tahun 1985 Nomor 75, Tambahan Lembaran Negara Nomor 3318).

[10]. Undang-Undang nomor 4 tahun 1992 Tentang Perumahan dan Permukiman (Lembaran Negara Republik Indonesia tahun 1992 nomor 23, Tambahan Lembaran Negara nomor 3469).

[11]. Undang-Undang Nomor 28 Tahun 2002 Tentang Bangunan Gedung (Lembaran Negara Republik Indonesia tahun 2002 nomor 134, Tambahan Lembaran Negara Republik Indonesia tahun 2002 Nomor 4247).

[12]. Undang-Undang Nomor 1 Tahun 2011 Tentang Perumahan dan Kawasan Permukiman (Lembaran Negara tahun 2011 nomor 7 , Tambahan Lembaran Negara Republik Indonesia Nomor 5188). 